\title{
Physicochemical, microbiological and sensory characterization of liquor obtained from atemoya fruit (Annona cherimola $\times$ Annona squamosa)
}

\author{
Caracterización fisicoquímica, microbiológica y sensorial del licor obtenido a partir del \\ fruto de atemoya (Annona cherimola $\times$ Annona squamosa)
}

\author{
J. Martínez-Girón ;A.L. Arias-Rodas ; J.C. Hernández-Montaña iD , J.H. Agudelo-Burbano iD, B. \\ Reina-Hernandez iD
}

\begin{abstract}
The In this study the physicochemical, microbiological and sensorial characterization of the liquor obtained from atemoya fruit. The fermented beverage was made using fruit pulp (5\%), water (78 \%), acidulant (citric acid $0.04 \%$ ), pH regulator (diammonium phosphate $0.04 \%$ ), sugar $(15 \%)$ and yeast (Saccharomyces cerevisiae $1.92 \%$ ). The process of obtaining the liquor included a stage of selection, cleaning and disinfection of the fruit, characterization of the pulp, pulping, mixing, fermentation, filtration, clarification and packaging. The obtained results evidenced a good sensory acceptance in relation to the texture, color, flavor and smell. A pH of 3.78, volatile acidity of $0.08 \%$, density of $1.10 \mathrm{~g} / \mathrm{mL}$, reducing sugars of $10.56 \%$, alcohol grade of $9.77^{\circ} \mathrm{GL}$, percentage of $67 \mathrm{ppm}$ methanol, E. coli absent, $90 \mathrm{CFU} / \mathrm{mL}$ aerobic mesophiles count, and $50 \mathrm{UFC} / \mathrm{mL}$ yeast and fungal counts. Given the above, it is concluded that the liquor obtained is a physicochemical, microbiological and sensorial stable drink, because it meets the quality requirements of Colombian Technical Standard 708 of 2000, established for fruit wines.
\end{abstract}

Index Terms-Fermentation, alcohol degree, $\mathrm{pH}$, fruit pulp

Resumen-En este estudio se realizó la caracterización fisicoquímica, microbiológica y sensorial del licor obtenido a partir del fruto de atemoya. La bebida fermentada fue elaborada empleando pulpa de fruta $(5 \%)$, agua $(78 \%)$, acidulante (ácido cítrico $0.04 \%$ ), regulador de pH (fosfato diamónico $0.04 \%$ ), azúcar (15\%) y levadura (Saccharomyces cerevisiae $1.92 \%)$. El proceso de obtención del licor incluyó una etapa de selección, limpieza y desinfección del fruto, caracterización de la pulpa, despulpado, mezclado, fermentación, filtración, clarificación y envasado. Los resultados obtenidos evidenciaron una buena aceptación sensorial en relación a la textura, color, sabor y olor. Se obtuvo en el producto final un $\mathrm{pH}$ de 3.78 , acidez volátil de 0.08 $\%$, densidad de $1.10 \mathrm{~g} / \mathrm{mL}$, azúcares reductores de $10.56 \%$, grado de alcohol de $9.77{ }^{\circ} \mathrm{GL}$, porcentaje de metanol de $67 \mathrm{ppm}$, E. coli ausente, recuento de mesófilos aerobios de $90 \mathrm{UFC} / \mathrm{mL}$ y recuento de hongos y levaduras de $50 \mathrm{UFC} / \mathrm{mL}$. Dado lo anterior, se concluye que el licor obtenido es una bebida estable desde el punto de vista fisicoquímico, microbiológico y sensorial, debido a que

This manuscript was sent on January 19, 2019 and accepted on May 20, 2019. This work was supported by the Universidad del Valle-Sede Palmira.

J. Martínez-Girón, Universidad del Valle-Sede Palmira. Carrera 31 Avenida la Carbonera. Valle del Cauca. Colombia.

A.L. Arias-Rodas Universidad del Valle-Sede Palmira. Carrera 31 Avenida la Carbonera. Valle del Cauca. Colombia. cumple con los requisitos de calidad exigidos por la Norma Técnica Colombiana 708 de 2000 , establecida para vinos de frutas.

Palabras Claves-Fermentación, grado de alcohol, pH, pulpa de fruta.

\section{INTRODUCTION}

The atemoya fruit (Annona cherimola $\times$ Annona squamosa) has a pleasant flavor, high carbohydrate content and abundant ascorbic acids and nutrients. The atemoya is a typical climaterial fruit with a short shelf life during the postharvest period. A high rate of respiration and soluble solid contents are the main causes of the rapid deterioration of atemoya fruits [1].

The most cultivated species of the Annonaceae family, is an exotic subtropical fruit native to South America [2]. The cherimoya (Annona cherimola) is a climacteric fruit, the harvest time of the fruit is determined by the color of the skin, which changes from dark to light green or greenish yellow near physiological maturity [3]. Cherimoya is extremely susceptible to browning caused mainly by the activity of the polyphenol oxidase enzyme [2]. The ripening process occurs during climacteric respiration, and ripening occurs very quickly after harvest. In fact, high levels of ethylene (up to $100-300 \mu \mathrm{L} / \mathrm{kg}$ $\mathrm{hr}^{-1}$, depending on the cultivar), when mature, they can reach high concentrations of soluble sugars (14-15\%) and moderate titratable acidity (0.4-0.7\%). They are good sources of ascorbic acid $(45-60 \mathrm{mg} / 100 \mathrm{~g}$ ) and potassium $(250-500 \mathrm{mg} / 100 \mathrm{~g}$ of edible portion) [3]. One of the characteristics of deterioration is the softening of the fruit. The measurement of the firmness of the fruit is an adequate method to control the softening of the fruit during the post-harvest handling. The cherimoya is a very irregular and delicate fruit, so measuring firmness using impact methods is very difficult [4].

Annona squamosa also belongs to the Annonaceae family, with rough epicarp similar to pineapple; sugary mesocarp, white to bright yellow, the best taste among the family's fruits,

J.C. Hernández-Montaña, Universidad del Valle-Sede Palmira. Carrera 31 Avenida la Carbonera. Valle del Cauca. Colombia.

J.H. Agudelo-Burbano, Universidad del Valle-Sede Palmira. Carrera 31 Avenida la Carbonera. Valle del Cauca. Colombia, B. Reina-Hernández, Universidad Nacional de Colombia-Sede Palmira. Carrera 32 N 12-00. Valle del Cauca, Colombia 
crunchy or juice is consumed. The fruits weigh 100-230 g [5]. It has a large market of applications in the food industry due to its delicious meat and its special fragrance, it is even used as an antitumor, antidiabetic and antioxidant [6].

The anon is constituted by water $(72.6 \mathrm{~g})$, proteins $(1.68 \mathrm{~g})$, lipids $(0.4 \mathrm{~g})$, carbohydrates $(19.6 \mathrm{~g})$, fiber $(1.4 \mathrm{~g})$, total acidity $(0.1 \mathrm{~g})$, ash $(0.7 \mathrm{~g})$, energy (96 cal), calcium $(26.2 \mathrm{mg})$, phosphorus $(42 \mathrm{mg})$, iron $(0.8 \mathrm{mg})$, Vitamin A $(0.005 \mathrm{mg})$, Vitamins of the complex B: B1 $(0.1 \mathrm{mg})$, B12 $(0.13 \mathrm{mg})$, B5 $(0.9 \mathrm{mg}), \mathrm{B} 6(0.2 \mathrm{mg}), \mathrm{B} 2(0.113 \mathrm{mg}), \mathrm{B} 3(0.883 \mathrm{mg})$, ascorbic acid $(37.38 \mathrm{mg})$, per $100 \mathrm{~g}$ of edible pulp [5].

Due to its good nutritional and organoleptic qualities, atemoya fruit (Annona cherimola $\times$ Annona squamosa) of the Annonaceae family was chosen for the elaboration of this article. It should be noted that there is very little information about the liquor obtained from the atemoya fruit, for this reason this innovative product is created with the purpose of exploring a new additional value for this fruit, improving its use and also providing information for its reproduction.

\section{MATERIALS AND METHODS}

The procedures were made taking into account the parameters established in Resolution 2674 of 2013, which corresponds to the application of Good Manufacturing Practices (GMP) [7]. The process of making the drink was carried out according to the general requirements established in the NTC 708 of 2000 that establishes the parameters of alcoholic beverages and fruit wines [8].

\section{A. Obtaining the pulp}

The fruit was obtained from the farm Villa Esperanza (La Piña, Rozo, Valle del Cauca, Colombia). To obtain the pulp, a process of cleaning and disinfecting the plant material with sodium hypochlorite at $120 \mathrm{ppm}$ was carried out. We proceeded to remove the epicarp and the seeds, obtaining a yield in pulp of $54 \%$.

\section{B. Physicochemical analysis}

Humidity $(\%)$

The moisture content was determined by the gravimetric method described in AOAC 930.15 of 1990 [9]. Exactly two grams of each of the samples, then passed to a previously tared porcelain capsule. It was heated to $105^{\circ} \mathrm{C}$ using a F-260 Binder model drying oven, long enough to achieve a constant weight. It was cooled in a desiccator and weighed again.

Concentration of hydrogen ions $(\mathrm{pH})$

The $\mathrm{pH}$ was determined using the procedure NTC 440 of 2015 [10], in a Mettler Toledo MP 220 Basic pHmeter, which was previously calibrated. To perform the reading, $20 \mathrm{~mL}$ of the sample where the electrode was introduced was used. It is washed with distilled water before and after finishing the reading.

Ash
The ash content was determined by the gravimetric method described in AOAC 942.05 of 1990 [11]. Exactly $2 \mathrm{~g}$ of each of the samples were weighed in a previously tared porcelain crucible. It was placed in a model muffle Heraeus and calcined dark red $\left(550^{\circ} \mathrm{C}\right)$. The crucible was transferred directly to the desiccator, allowing it to cool to weigh it later.

\section{Raw fiber}

The crude fiber content was determined by the gravimetric method described in AOAC 985.29 [12]. Duplicate portions of the test were weighed. $\alpha$-amylase: gelatinizes. Phosphate buffer $(\mathrm{pH} 6.0,50 \mathrm{~mL}$ ) was added to the sample. It was adjusted to $\mathrm{pH}$ $6.0 \pm 0.2$. The enzyme was added, incubated at $95-100{ }^{\circ} \mathrm{C} .30$ min in water bath. Protease: proteins were eliminated. It was cooled to room temperature. It was adjusted to $\mathrm{pH} 7.5 \pm 0.2$. The enzyme was added, incubated at $60{ }^{\circ} \mathrm{C}$ for $30 \mathrm{~min}$. Amyloglucosidase: the starch was removed. It was adjusted to $\mathrm{pH} 4.0$ - 4.6. The enzyme was added, incubated at $60^{\circ} \mathrm{C}$ for 30 min. $280 \mathrm{~mL}$ of $95 \%$ ethyl alcohol $\left(60{ }^{\circ} \mathrm{C}\right)$ was added. The precipitate was allowed to form at room temperature for $60 \mathrm{~min}$. The residues (soluble fiber + insoluble fiber) were collected in crucibles of previous weight. A test portion for protein was used, using $\mathrm{N} \times 6.25$ as the conversion factor. The second test portion was incinerated at $525{ }^{\circ} \mathrm{C}$ for $5 \mathrm{~h}$. Total Dietary Fiber $=$ [weight residue - protein - ash - white] / weight test portion.

\section{Ascorbic acid}

The vitamin $\mathrm{C}$ content was determined by the procedure of NTC 440 of 2015, titration method [10]. Portions of at least 100 $\mathrm{mL}$ of prepared sample were taken, weighed and added to equal volumes of the extracting solution, mixed and quickly filtered through a fast filtration paper, $10 \mathrm{~mL}$ were titrated with the indophenol solution and blank tests were made to correct the titrations, as is normally done in the valuation of the indophenol solution, using appropriate volumes of the extracting solution and water. The content of ascorbic acid was calculated as follows:

$$
\begin{aligned}
& \text { Ascorbic acid } m g / L=\frac{1000 \mathrm{VC}}{G} \\
& \text { Where }
\end{aligned}
$$

$\mathrm{V}=$ volume of the indophenol solution used in the titration, in milliliters.

$\mathrm{C}=$ title of the solution of indophenol expressed in milligrams of ascorbic acid.

$\mathrm{G}=$ weight of the sample, in grams.

\section{Titratable acidity}

The titratable acidity was determined by the procedure of NTC 440 of 2015 [10], AOAC 942.15 of 1990 [13]. $1 \mathrm{~g}$ of the sample was weighed and diluted in $10 \mathrm{~mL}$ of distilled water, adding 3 drops of phenolphthalein indicator, it was titrated with sodium hydroxide $(\mathrm{NaOH})$ at a concentration of $0.1 \mathrm{~N}$ until obtaining a pink hue, to complete the titration ( $\mathrm{pH}$ 8.2). The percentage of acidity was calculated by the equation:

$\%$ Acidity $=\frac{\left(V_{1}\right)(N)(m e)}{V} \times 100$

Where

$\mathrm{V}=$ Volume of the sample in $\mathrm{mL}$. 
$\mathrm{V} 1=$ Volume of the $\mathrm{NaOH}$ solution used in the titration in $\mathrm{mL}$.

$\mathrm{N}=$ Normality of the $\mathrm{NaOH}$ solution.

me $=$ Weight in milliequivalents / gram of the predominant organic acid in the fruit.

The predominant organic acid in the fruit was malic acid. [3].

Total Soluble Solids ( ${ }^{\circ}$ Brix)

The determination of the soluble solids was carried out in the SCIENTIFIC-300053 digital refractometer of SPER by the procedure of NTC 440 of 2015 [10], AOAC 932.12 of 1990 [14], the refractometer was first washed with distilled water before the measurement, subsequently 3 drops of the sample were deposited, and it was expected that the value of the soluble solids would be indicated on the screen with their respective temperature.

\section{Maturity Index}

It was determined by the ratio of soluble solids divided by the percentage of acidity [15].

Density

The density was determined by the AOAC procedure 945.06, pycnometer method [16].

Degrees of Alcohol

The ethanol content was determined by NTC 5113 [17]. Using a Handheld density meter DMA 35 Basic (Anton Paar, Graz, Austria).

Volatile acidity

Volatile acidity was determined by the NTC 5114 procedure [18]. $25 \mathrm{~mL}$ of $\mathrm{CO}_{2}$-free wine was distilled by steam, $1 \mathrm{~mL}$ of $50 \%$ tartaric acid was added and the distillate was received in a $250 \mathrm{~mL}$ Erlenmeyer flask, which previously had $20 \mathrm{~mL}$ of distilled water. Approximately $250 \mathrm{~mL}$ were received and were titrated with $\mathrm{NaOH}$ solution in the presence of a few drops of phenolphthalein to pink coloration.

The volatile acidity, expressed in grams of acetic acid / L or per $\mathrm{dm} 3$, was calculated as:

$$
\text { Volatile acidity }=\frac{V \times N \times 0.06}{20} \times 1000
$$

Methanol

The methanol concentration was determined by NTC 4118 , gas chromatography method [19]. The working solution of the response factors (solution C) was analyzed chromatographically (Shimadzu-17A Kyoto, Japan equipped with flame ionization detector (FID) and an integrator C-R6A Chromatopac). The areas (heights) of all the components including the internal standard were measured. The theoretical concentration of the compounds of the solutions, response factors, standard solution of quality control and those of the internal standard were calculated using calculations. The standard quality control solution prepared was analyzed chromatographically and the measured concentrations (obtained in the analysis) were compared with the theoretical concentrations (obtained by calculations).
Reducing Sugars

It was determined by NTC 440 [10]. To $10 \mathrm{~mL}$ or $25 \mathrm{~mL}$ of the mixed Soxhlet solution, $15 \mathrm{~mL}$ of the sugar solution was added and boiled on a heating plate. After $15 \mathrm{~s}$ of boiling, new portions of the sugar solution were quickly added until only a faint blue color remained. $1 \mathrm{~mL}$ of $0.2 \%$ aqueous solution of methylene blue (or 3 - 4 drops of $1 \%$ solution) was added and the titration was completed by adding a solution of sugar per drops. For greater precision the titration was repeated adding almost all the sugar solution necessary to reduce all the copper. Subsequently, by tables, the reducing sugar was found, where the tabulated factor corresponding to the number of milliliters used was found and the percentage of reducing sugars, expressed as invert sugar, was calculated as follows:

$$
\text { Invert sugar }=\frac{80 \times \text { tabulated factor } x \text { correction }}{G \times V}
$$

Where:

$\mathrm{G}=$ weight of the original sample, in grams

$\mathrm{V}=$ volume of the sample solution used in the final titration, in milliliters

$$
\text { Correction }=\text { factor found in the Fehling titration }
$$

\section{Microbiological parameters}

E.coli

For E.coli, it was determined following the procedure of NTC 4458 [20]. Two sterile Petri dishes were taken. Using a pipette, $1 \mathrm{~mL}$ of the test sample was transferred to each box. Two sterile Petri dishes were taken. Using another pipette, $1 \mathrm{~mL}$ of the first decimal dilution $\left(10^{-1}\right)$ was transferred to each box. Approximately $10 \mathrm{~mL}$ to $15 \mathrm{~mL}$ of the specific medium was poured at $45^{\circ} \mathrm{C} \pm 2{ }^{\circ} \mathrm{C}$ in each Petri dish. The time elapsed between the end of the preparation of the dilution $10^{-1}$ and the moment in which the medium was poured into the boxes was not greater than $20 \mathrm{~min}$. The inoculum was mixed with the medium and the mixture was allowed to solidify, the Petri dishes being on a cold horizontal surface. After the solidification was completed, approximately $4 \mathrm{~mL}$ of culture medium that covered the surface at $45^{\circ} \mathrm{C} \pm 2{ }^{\circ} \mathrm{C}$ was poured onto the surface of the inoculated medium. It was allowed to solidify as in the previous process. There was a double layer to better visualize the colonies. The prepared boxes were inverted and incubated at $35^{\circ} \mathrm{C} \pm 1^{\circ} \mathrm{C}$ for $24 \mathrm{~h} \pm 2 \mathrm{~h}$. After the incubation period, boxes that did not contain more than 150 colonies were selected. Colonies of typical and non-typical coliforms were counted in each box. The morphology of the colonies was recorded according to the culture medium used. Using a fluorescence lamp of $360 \mathrm{~nm}$ at $366 \mathrm{~nm}$, the positive fluorescence E. coli bacteria was read.

\section{Aerobic mesophiles}

For the count of aerobic mesophiles, it was determined following the procedure of NTC 4519 [21]. Two sterile Petri dishes were taken. Using a pipette, $1 \mathrm{~mL}$ of the test sample was transferred to each box. Two sterile Petri dishes were taken. Using another pipette, $1 \mathrm{~mL}$ of the first decimal dilution $\left(10^{-1}\right)$ was transferred to each box. Approximately $10 \mathrm{~mL}$ to $15 \mathrm{~mL}$ of the specific medium was poured at a temperature between $44^{\circ}$ 
$\mathrm{C}$ and $47^{\circ} \mathrm{C}$, in each Petri dish. The time elapsed between the end of the preparation of the dilution $10^{-1}$ and the moment in which the medium was poured into the boxes was not greater than $15 \mathrm{~min}$. The inoculum was mixed with the medium and the mixture was allowed to solidify, the Petri dishes being on a smooth horizontal surface. After the solidification was completed, approximately $4 \mathrm{~mL}$ of culture medium that covered the surface at a temperature between $44^{\circ} \mathrm{C}$ and $47^{\circ} \mathrm{C}$ was poured onto the surface of the inoculated medium. It was allowed to solidify as in the previous process. The prepared boxes were inverted and incubated at $30^{\circ} \mathrm{C} \pm 1{ }^{\circ} \mathrm{C}$ for $72 \mathrm{~h} \pm$ $3 \mathrm{~h}$. After the incubation period, the colonies were counted in each box. Petri dishes were examined under dim light.

\section{Mushroom and yeast}

For the count of molds and yeasts, it was determined following the procedure of the NTC 5698-1 [22]. A DRBC agar plate was taken, using a sterile pipette, $0.1 \mathrm{~mL}$ of the test sample was transferred. A second DRBC agar plate was taken, using a sterile pipette, $0.1 \mathrm{~mL}$ of the first $10^{-1}$ decimal dilution was transferred. Volumes of up to $0.3 \mathrm{~mL}$ of a $10^{-1}$ dilution of the sample were dispersed over 3 boxes. The liquid was dispersed on the surface of the agar plate with a sterile spreader until the liquid was completely absorbed in the medium. The plates prepared at $25^{\circ} \mathrm{C} \pm 1^{\circ} \mathrm{C}$ for 5 days were incubated aerobically in inverted position. The agar plates were left at rest in diffuse natural light during the first two days. Then it was incubated in an open plastic bag so as not to contaminate the incubator, with mold growth outside the box.

\section{Formulation of the must.}

The must was prepared at $20-22{ }^{\circ}$ Brix with the addition of sucrose (common sugar) and corrected to a $\mathrm{pH}$ of about 3.0 3.5 with citric acid or sodium bicarbonate. The acidity of the must was between $0.5 \%$ and $0.9 \%$, which was ideal for fermentation. Before adding the must to the fermentation vessel (reactor), sulfation was carried out in order to destroy or inhibit the development of many undesirable types of microorganisms (acetic bacteria, wild yeasts and molds), giving way to the true yeast alcoholic, through the addition of $0.2 \mathrm{~g}$ of metabisulfite per liter of must. Fermentation began, taking into account the conditions of the process, such as temperature, sugar concentration and $\mathrm{pH}$. This ended when the yeast consumed all the fermentable sugars. The presence and operation of the air bag is important in the process, because it facilitated the exit of the $\mathrm{CO}_{2}$ produced during the fermentation and prevented the entry of air and, therefore, oxygen in the fermenter.

\section{E. Fermentation}

Yeast previously activated at $30{ }^{\circ} \mathrm{C}$ was used for the fermentation process.

\section{F. Filtration and clarification}

In this operation the solid particles of the fluid were separated through clarification, this was done adding $0.03 \%$ pectinases until obtaining the appearance of color, smell and flavor characteristic of the fermented fruit liquor.

\section{G. Packaging}

The product obtained was packed in $350 \mathrm{~mL}$ amber plastic bottles, these bottles protect the drink from light and reduce the risk of oxidation in the drink.

\section{ANALYSIS OF RESULTS}

In the pulp process a yield of $54 \%$ was obtained due to the high amount of seeds that these fruits have, which is low in comparison with the studies carried out by reference [23].

Table I presented the physicochemical tests of the pulp, comparing them with the reference results [15] that were similar, which means that the pulp was in optimum conditions for the production of liquor. Reference [24] reported a $\mathrm{pH}$ value similar to pulp, moisture and titratable acidity. The reference [25] reported the $\mathrm{pH}$ value in the anon pulp, as a range, in which the $\mathrm{pH}$ of the atemoya pulp was found in this work. As for the ashes in this study, it was $0.67 \%$, a value similar to that reported by reference [26].

TABLE I

PHYSICOCHEMICAL TESTS IN THE PULP

\begin{tabular}{cc}
\hline \hline Physicochemical property & Result \\
\hline Humidity & $78.45 \pm 1.14$ \\
pH & $5.12 \pm 0.01$ \\
Ash (\%) & $0.67 \pm 0.02$ \\
Crude fiber (\%) & $8.14 \pm 0.74$ \\
Vitamin C (\%) & $3.89 \pm 0.56$ \\
Titratable acidity (\%) & $0.97 \pm 0.02$ \\
Total Soluble solids ( ${ }^{\circ}$ Brix) & $8.20 \pm 0.03$ \\
Density (g/mL) & $1.22 \pm 0.01$ \\
Maturity Index & $8.45 \pm 0.04$ \\
\hline \multicolumn{2}{c}{ Source: Authors }
\end{tabular}

TABLE II

PHYSICOCHEMICAL AND MICROBIOLOGICAL TESTS IN FRUIT LIQUOR

\begin{tabular}{ll}
\hline \hline \multicolumn{1}{c}{ Physicochemical property } & \multicolumn{1}{c}{ Result } \\
\hline $\mathrm{pH}$ & $3.78 \pm 0.02$ \\
Volatile acidity (\%) & $0.08 \pm 0.01$ \\
Density (g/mL) & $1.10 \pm 0.03$ \\
Reducing sugars (\%) & $10.56 \pm 0.58$ \\
Alcohol content (\%) & $9.77 \pm 0.47$ \\
Methanol percentage (ppm) & $67 \pm 0.79$ \\
\hline \multicolumn{1}{c}{ Microbiological parameters } & Result \\
\hline E.coli $(\mathrm{UFC} / \mathrm{mL})$ & Absent \\
Mesophilic aerobic count (UFC/mL) & $90 \pm 1.16$ \\
Mushroom and yeast count (UFC/mL) & $50 \pm 1.37$ \\
\hline \hline
\end{tabular}

Source: Authors

Table II presented the physicochemical tests of atemoya liquor, where the $\mathrm{pH}$ is 3.78 . This value is in the acceptance range, between 2.8 and 4.0, according to NTC 708 [8]. Reference [27] reported a pH of 3.72 in apricot wine, a value close to that obtained in this wine. Reference [28] in their pears wines gave $\mathrm{pH}$ values between 3.53 and 4.93 , similar to $\mathrm{pH} 3.78$ of atemoya wine. Reference [29] in their fruit wine based on Tamarind (Tamarindus indica L.) and starfruit (Averrhoa 
carambola $L$.) determined a $\mathrm{pH}$ of 3.07 , a value close to $\mathrm{pH} 3.7$. The reference [30] in its borojo wine (B patinoi Cuatrec), obtained a $\mathrm{pH}$ of 3.5 , close to the $\mathrm{pH}$ of this work. The reference [31] in its evaluation of mixed fruit wines (watermelon, pineapple, orange) produced from physically damaged fruits reported a pH value of 3.93 at 64 days of fermentation, is close to that obtained in this work. The reference [32] with its wines of Cabernet Sauvignon (Vitis Vinifera L.) reported a pH of 3.78 in the treatment.

The volatile acidity of the liquor was $0.8 \mathrm{~g} / \mathrm{dm}^{3}(0.08 \%)$, a result that is below $1.2 \mathrm{~g} / \mathrm{dm}^{3}$, which is the maximum allowed in NTC 708 [8]. Reference [33] Merlot wine, a volatile acidity of $0.74 \mathrm{~g} / \mathrm{L}$ was determined. Reference [29] obtained a volatile acidity of $0.11 \mathrm{~g} / \mathrm{dm}^{3}$, value close to $0.8 \mathrm{~g} / \mathrm{dm}^{3}$. Reference [34] in the elaboration and characterization of tejocote wine (Crataegus mexicana), reported a volatile acid value of $0.8 \mathrm{~g} / \mathrm{L}$, identical to the value obtained in this work. This result can be compared with the volatile acidity in the lulo vinous aperitif (Solanum quitoense l.) made in a fermentation that stopped after 12 days with a volatile acidity of $1.1 \mathrm{~g} / \mathrm{dm}^{3}(0.11 \%)$, which also meets the standards required [35]. Volatile acidity is the measure of the volatile acids of the acetic acid series, which are found in wine in free form or as combined salts [36].

The reference [37] in its work for the production of sparkling wines with $T$. delbrueckii, obtained a density of $0.995 \mathrm{~g} / \mathrm{mL}$, a lower value compared to $1.10 \mathrm{~g} / \mathrm{mL}$ in this work. Reference [38] reported a density of $0.9915 \mathrm{~g} / \mathrm{mL}$ in fruit wine subjected to a high hydrostatic pressure, as an oenological practice for the aging of red wine. Since density is a specific property of matter, it can be used to determine the purity of a material, since it is significantly modified by the presence of contaminants [36].

Our liquor had reducing sugars of $10.56 \%\left(105.6 \mathrm{~g} / \mathrm{dm}^{3}\right)$, a result close to that obtained in the production of wine with kefir culture immobilized in pieces of apple that was $120.4 \mathrm{~g} / \mathrm{L}$ [39]. The liquor based on peach (Prunus persica) "huayco" had 87.2 $\mathrm{g} / \mathrm{dm}^{3}$ [40]. The young wine of borojo fruit (B patinoi Cuatrec) in its result with total sugars of $0.5 \mathrm{~g} / \mathrm{dm}^{3}$ [30]. Our liquor ended up as sweet liquor, according to NTC 708 , above $50.1 \mathrm{~g} / \mathrm{dm}^{3}$ [8]. The reference [33] in his wine traminer obtained $5.80 \mathrm{~g} / \mathrm{L}$ in the treatment of wines subjected to $1300 \mathrm{~Gy}$. Reference [41] reported a sugar reduction of $27.52 \mathrm{~g} / \mathrm{L}$ in cranberry wine.

Reference [27] reported the alcoholic content (Ethanol) 9.91 $\%$ in apricot wine, a value close to that obtained in this wine of $9.77 \%$. In the production of wine with immobilized kefir culture on grape skins it was $9.5 \%$ [39]. According to NTC 708 , the minimum content of breathalyzer degrees is $6 \%$, so this liquor complies with the regulations [8]. The vinous lulo aperitif (Solanum quitoense l.) reported an alcohol quantity of $11.3 \%$ [35]. The young borojo fruit wine (B Cuatrec patinoi) in its result with an alcohol level of $9.25 \%$ [30]. The reference [42] in his work on jambolan wine (Syzygium cumini) fermented with grape seed, registered $9.32 \%$, result similar to the value of alcohol in this work.

According to the NTC 708 standard, the maximum content of methanol in a fruit wine is $1000 \mathrm{mg} / \mathrm{dm}^{3}$ [8]. This regulation was fulfilled because the atemoya wine produced $67 \mathrm{mg} / \mathrm{dm}^{3}$ of methanol, measured by gas chromatography procedure. The vinous lulo appetizer (Solanum quitoense $l$.) reported methanol of $108 \mathrm{mg} / \mathrm{dm}^{3}$ [35]. While the young borojo wine fruit $(B$ patinoi Cuatrec) in its result with methanol grade of 31.74 $\mathrm{mg} / \mathrm{dm} 3$ [30]. Our wine complied with European regulations, in terms of maximum methanol content in countries such as Spain, France, Portugal and Italy [35].

With respect to microbiological parameters, the aerobic count of mesophiles and the fungal count for this product was below the maximum normative levels, similar to the data in the reference [35]. It should be noted that the E. coli test was 0 , which means that this product is safe and innocuous for human consumption.

In Table III, sensory analysis was presented indicating the organoleptic characteristics of the atemoya fruit (Annona cherimola $\times$ Annona squamosa) that could be perceived through the physical characteristics that contain fruit or food.

TABLE III

SENSORIAL ANALYSIS (9-POINT HEDONIC SCALE)

\begin{tabular}{llllllllll}
\hline \hline Attributes & Texture & Color & Flavor & Smell & Acceptance \\
& & & & & & & \\
\hline Fruit liquor & 7.70 & \pm & 8.12 & \pm & 8.60 & \pm & 7.90 & \pm & $8.47 \pm 1.08$ \\
& 1.22 & & 0.56 & & 0.30 & & 0.75 & & \\
& & & & & & & & & \\
\end{tabular}

Source: Authors

The results of the atemoya drink investigation showed a texture of $7.70 \pm 1.22$, color $8.12 \pm 0.56$, flavor $8.60 \pm 0.30$, smell $7.9 \pm 0.75$ and finally an acceptance of $8.47 \pm 1.08$, which indicated that the product presented a good sensory acceptance, using a hedonic scale of 9 points with the following descriptors:

I disliked extremely $=1$

I did not like it much $=2$

I did not like moderately $=3$

I did not like it lightly $=4$

It's indifferent to me (I did not like it, it did not displease me) $=5$

I liked it slightly $=6$,

I like it moderately $=7$

I liked it a lot $=8$

I liked it extremely $=9$

The sensory analysis was a very important step in the work with the characterization of the drink. Especially for fruit wines, this analysis provided interesting results because most fruit wines are characterized by aromatic nuances typical of the fruits used [36]. Reference [43] presented similar results in their coconut water wine in terms of color of 8.72 and aroma of 7.27, values that are found in the acceptance region, which is between 6 and 9. However, atemoya wine presented appearance values of 7.70 and acceptance of 8.47 , which was lower compared to those reported in coconut water wine. In general terms, it can be said that the atemoya wine had a good general acceptance and a great reception from the untrained panels, which tasted the wine. 


\section{CONCLUSIONS}

The product met the parameters and standards allowed by the legislation or the quality requirements required by the Colombian Technical Standard 708 of 2000. A liquor with an alcohol grade of $9.77 \% \mathrm{v} / \mathrm{v}$ was obtained, which is enough to be considered high quality and harmless fruit liqueur. Although the fruit have a good acceptance in the country, there is no adequate use of it, so the additional value that could be given to the main fruits of this article is high, since it had a good acceptance in the surveyed population.

\section{REFERENCES}

[1] K. Liu et al., "Comparative transcriptomic analysis of split and non-split atemoya (Annona cherimola Mill. $\times$ Annona squamosa $\mathrm{L}$.) fruit to identify potential genes involved in the fruit splitting process", Sci Hortic, vol. 248, pp. 216-224, Apr. 2019, DOI: 10.1016/j.scienta.2019.01.017

[2] P. Olmedo et al., "A catechol oxidase AcPPO from cherimoya (Annona cherimola Mill.) is localized to the Golgi apparatus", Plant Sci, vol. 266, pp. 46-54, Jan. 2018, DOI: 10.1016/j.plantsci.2017.10.012

[3] G. Gullo et al., "Effect of fruit-set time on the quality performance of Anona cherimola Mill. fruit in south Italy", Sci Hortic, vol. 246, pp. 272278, Feb. 2019, DOI: 10.1016/j.scienta.2018.10.021

[4] C. Ortiz, C. Blanes and M. Mellado, "An ultra-low pressure pneumatic jamming impact device to non-destructively assess cherimoya firmness", BIOSYST ENG, vol. 180, pp. 161-167, Apr. 2019, DOI: 10.1016/j.biosystemseng.2019.02.003

[5] M. Murtala et al., "Sugar apple - Annona squamosa Linn", in Exotic Fruits Reference Guide, Fortaleza, CE, BR: AP, 2018, pp. 397-402.

[6] Z. Zhen et al., "Structural characterization and inhibition on $\alpha$-glucosidase activity of acidic polysaccharide from Annona squamosa", Carbohyd Polym, vol. 174, pp. 1-12, Oct. 2017, DOI: 10.1016/j.carbpol.2017.05.092

[7] Good Manufacturing Practices, Resolution 2674, 2013.

[8] Alcoholic drinks. Fruit wine, NTC 708, 2000.

[9] Association of Official Agricultural Chemists, AOAC 930.15, 1990.

[10] Food products. Test methods, NTC 440, 2015.

[11] Association of Official Agricultural Chemists, AOAC 942.05, 1990.

[12] Association of Official Agricultural Chemists, AOAC 985.29, 1985.

[13] Association of Official Agricultural Chemists, AOAC 942.15, 2005.

[14] Association of Official Agricultural Chemists, AOAC 932.12,1990.

[15] G. Arrazola, J. Barrera and M. Villalba, "Determinación física y bromatológica de la guanábana cimarrona (Annona glabra L) del departamento de Córdoba", Unillanos, vol. 17, no. 2, pp. 159-166, Ag. 2013

[16] Association of Official Agricultural Chemists, AOAC 945.06,1990.

[17] Alcoholic drinks. Methods to determine the alcohol content, NTC 5113, 2018.

[18] Alcoholic drinks. Method to determine acidity and pH, NTC 5114, 2003.

[19] Alcoholic drinks. Determination of methanol and congeners in alcoholic beverages and in ethyl alcohol used in its preparation, by gas chromatography, NTC 4118, 1997.

[20] Microbiology of food and food for animals. Horizontal method for the coliform recording or Escherichia coli or both. Colony counting technique using fluorogenic or chromogenic media, NTC 4458, 2018.

[21] Microbiology of the foods for animal and human use. Horizontal method for the counting of microorganisms. Colony collection technique at $30^{\circ} \mathrm{C}$, NTC 4519, 2009.

[22] Microbiology of food and animal feed. Horizontal method for the enumeration of molds and yeasts. Part 1: colony counting technique in products with aqueous activity (aw) greater than 0.95, NTC 5698-1, 2009.
[23] H. Ghazali et al., "Characterization of enzyme-liquefied soursop (Annona muricata L.) puree", LWT-Food Sci Technol, vol. 94, pp. 40-49, Aug. 2018, DOI: 10.1016/j.lwt.2018.04.027

[24] G. Berumen, M. Hernández and M. Tiznado, "Utilization of biotechnological tools in soursop (Annona muricata L.)", Sci Hortic, vol. 245, pp. 269-273, Feb. 2019, DOI: 10.1016/j.scienta.2018.10.028

[25] A. Egydio and D. Santos, "Nutritional value of the pulp of different sugar apple cultivars (Annona squamosa L.)", in Nutritional Composition of Fruit Cultivars, UK: AP, 2016, ch. 9, pp. 195-214.

[26] A. Ceballos, G. Giraldo and C. Orrego, "Effect of freezing rate on quality parameters of freeze dried soursop fruit pulp", J Food Eng, vol. 111, no. 2, pp. 360-365, July 2012, DOI: 10.1016/j.jfoodeng.2012.02.010

[27] U. Čakar et al., "Fruit as a substrate for a wine: A case study of selected berry and drupe fruit wines", Sci Hortic, vol. 244, pp. 42-49, Jan. 2019, DOI: 10.1016/j.scienta.2018.09.020

[28] W. Jianping et al., "Characteristic fruit wine production via reciprocal selection of juice and non-Saccharomyces species", Food Microbiol, vol. 79, pp. 66-74, June 2019, DOI: 10.1016/j.fm.2018.11.008

[29] H. Pájaro, J. Benedetti and L. García, "Caracterización Fisicoquímica y Microbiológica de un Vino de Frutas a base de Tamarindo (Tamarindus indica L.) y Carambola (Averrhoa carambola L.)", Inf. Tecnol, vol. 29, no. 5, pp. 123-130, Oct. 2018, DOI: 10.4067/S0718-07642018000500123

[30] L. García, C. Florez and Y. Marrugo, "Elaboración y caracterización fisicoquímica de un vino joven de fruta de borojó (B patinoi Cuatrec)", Ci, Docencia y Tecnol, vol. 27, no. 52, pp. 507-519, My. 2016.

[31] D. Oba et al., "Data on microbial and physicochemical assessment of mixed fruit wine produced from physically damaged fruits", Data Brief, vol. 19, pp. 678-686, Aug. 2018, DOI: 10.1016/j.dib.2018.05.104

[32] J. Yan et al, "Anthocyanin accumulation and biosynthesis are modulated by regulated deficit irrigation in Cabernet Sauvignon (Vitis Vinifera L.) grapes and wines", Plant Physiol Biochem, vol. 135, pp. 469-479, Feb. 2019, DOI: 10.1016/j.plaphy.2018.11.013

[33] M. Mihaljević et al., "Gamma irradiation as pre-fermentative method for improving wine quality", LWT-Food Sci Technol, vol. 101, pp. 175-182, Mar. 2019, DOI: 10.1016/j.lwt.2018.11.016

[34] A. Ronquillo et al., "Elaboración y caracterización de vino de frutas e infusión de hierbas", Inv y D en Ci y Tecnol de Alimentos, vol. 1, no. 1, pp. 366-371, 2016.

[35] C. Granados et al., "Evaluación fisicoquímica y microbiológica del aperitivo vínico de lulo (Solanum quitoense)", Inf Tecnol, vol. 24, no. 6, pp. 35-40, Jul. 2013, DOI: 10.4067/S0718-07642013000600006

[36] D. Dias, W. Duarte and R. Schwan,"Methods of Evaluation of Fruit Wines", in Science and Technology of Fruit Wine Production, CN: AP, 2017, ch. 5, pp. 227-252.

[37] M. Ramírez et al., "Using Torulaspora delbrueckii killer yeasts in the elaboration of base wine and traditional sparkling wine" Int $J$ Food Microbiol, vol. 289, pp. 134-144, Jan. 2019, DOI: 10.1016/j.ijfoodmicro.2018.09.010

[38] C. Nunes et al., "Comparison of high pressure treatment with conventional red wine aging processes: impact on phenolic composition", Food Res Int, vol. 116, pp. 223-231, Feb. 2019, DOI: 10.1016/j.foodres.2018.08.018

[39] Y. Kourkoutas et al., "Wine production using free and immobilized kefir culture on natural supports". Food Chem, vol. 272, pp. 39-48, Jan. 2019, DOI: 10.1016/j.foodchem.2018.08.015

[40] E. Corcino et al., "Elaboración y aceptabilidad de licor a base de melocotón (Prunus persica) [huayco]”, UNJFSC, pp. 1-15. Ag. 2013.

[41] L. Shuxun et al., "Chemical composition of bilberry wine fermented with non-Saccharomyces yeasts (Torulaspora delbrueckii and Schizosaccharomyces pombe) and Saccharomyces cerevisiae in pure, sequential and mixed fermentations", Food Chem, vol. 266, pp. 262-274, Nov. 2018, DOI: 10.1016/j.foodchem.2018.06.003

[42] K. VenuGopal, C. Cherita, and K. Anu, "Augmentation of chemical and organoleptic properties in Syzygium cumini wine by incorporation of 
grape seeds during vinification", Food Chem, vol. 242, pp. 98-105, Mar.

2018, DOI: 10.1016/j.foodchem.2017.09.029

[43] L. Soares et al., "Coconut water wine: physicochemical and sensory evaluation", Rev. Cienc. Tecnol., no. 26, pp. 19-25, Dec. 2016. 